REFLECTIONS:

NEUROLOGY AND

THE HUMANITIES

Section Editor

Anne W. McCammon,

MD, FAAN

Daniel C. Potts, MD

Correspondence \& reprint requests to Dr. Potts: dpotts@nctpc.com
Supplemental data at www.neurology.org

Supplemental Data



\title{
The art of preserving personhood
}

Step into her world. She is still there.

Sometimes you wonder, don't you? If she were still the one you knew and loved, why would she look at you that way, so blankly? How could your face and touch be so unfamiliar to her at times, when it used to be so comforting? After all you do to care for her, why on earth would she lash out at you ... why would she insult you and try to hurt you? How could anything, even this, make her forget you? And why does she always look for home?

You've tried to bring her back, to lead her by the hand to life with you again. There are those moments, those awakenings, in which you feel you've broken through. But then it returns: the drifting back into the fog of unawareness. And the spark is gone.

Her world is sometimes one of darkness, of wandering, of isolation. She often sees and experiences things she should recognize and know, but cannot understand them. Warped perceptions of reality close in on her existence, at times evoking panic and fear. She tries to escape to something she knows, something which will comfort her and give her peace. But every door leads only to another unfamiliar room, cluttered like a patternless gauntlet. Her life seems like a room with a keyless, locked door.

But yet you know some seed of her must still be there. You see it at times, beautiful and true. May's rose is a still a rose in December, is it not? Do petals touched make the plant? Does blossoming perfume make the flower, or something more? Is a garden loved in winter as in spring?

How can this loved one be reached? You know her soul's light still burns. Can dementia's frozen walls be broken so that hearthside warmth of home again is known?

The way Alzheimer disease (AD) dismantles many of the self's cognitive elements is one of the greatest tragedies of the disorder. With this can go the loss of realized self-worth (at least the portion based on occupation, productivity, and societal identity) and dignity suffers profoundly. Human beings need to create, to be productive, to be independent, to be loved, and to be in community with others who understand them. They also need to be able to share their life stories and experience the life stories of others. AD and other dementias adversely affect all of these things. But elements of the emotional self may remain even in the condition's advanced stages. A kind word spoken, a gentle touch, smiling eye contact, the sharing of a story or song, and communicating in ways that affirm people in their present condition all validate personhood and foster its expression. And when personhood is strengthened, dementia's hold is weakened.

While current therapy cannot significantly alter the disease process, this is also a call for physicians to "think outside the box," to make a paradigm shift in our efforts to help these individuals and improve their quality of life. While prevention and cure are still primary goals, shouldn't we broaden our focus toward making each moment of their lives as good as it can be? Shouldn't we use the tools we have to facilitate self-expression, creativity, communication, understanding, and restoration of dignity? And shouldn't we use these tools to document a life story that might be lost to the world and to the patients themselves? What benefits might such efforts afford patients and caregivers, as well as families and friends? Could this be a means to "break the ice" and reach the warmth of their inner selves?

Time pressure and depersonalization of care threaten our health care system as much as rising costs and lack of access. The model we have created provides no incentives for actually taking care of the core of a human being, for tuning all our senses toward their expressions of need, for administering healing therapies from the inside out, and for addressing caregiver needs.

One approach that has proven usefulness is the employment of expressive arts therapies (art, music, poetry, drama, and dance/movement therapies, coupled with reminiscence). Art in all forms has the ability to meld the heart and mind of the artist with that of the observer, to call to consciousness in one

Listen to Dr. Potts read this essay (audio file on www.neurology.org). Beginning with the March 27 issue, this feature will be available exclusively on Neurology ${ }^{\circledR}$ for the $\mathrm{iPad}^{\circledR}$. 
human being the depth of emotion, experience, spirituality, and intellect behind the creation of the artistic work. I believe art, in all its forms, to be the purest medium of human connection, the one which most truly promotes holistic communion between individuals. ${ }^{1}$

Artistic expression thus helps to bypass roadblocks to communication and community caused by dementia, and it can fulfill the human need to create and be productive. It can even make a person "known" to others who find interaction challenging. In this way, the arts help to strengthen the relational identity of persons with $\mathrm{AD}$, at a time when their occupational and societal identities may be suffering. Benefits of expressive arts therapy include improvements in behavior, communication, sense of wellbeing, cognition, and social skills. Expressive arts therapies facilitate the telling of life stories that can no longer be conventionally told. When such therapies are utilized as an essential element of personcentered care (care that validates the person despite the illness rather than focusing on the disease itself), dignity and perceived self-worth are improved and positive family and caregiver interactions are facilitated. In short, healing is fostered for all.

Have those of us who are health care providers missed our mark to some extent? Do we have to prescribe medications or administer cures to fulfill the Hippocratic Oath? Shouldn't we direct more effort toward improving quality of life, restoring wholeness, promoting "purity and integrity of self," even if this requires a change in modus operandi? Does this not constitute healing, by definition? I believe it does, and assert the arts as a primary means that should be supported and utilized within the structure of person-centered caregiving models.

Yes, indeed, she is still there. And we must speak to her in the language of the soul.

\section{REFERENCE}

1. Potts D, Miller B. Expressive arts therapies in geriatric neurology. In: A Handbook of Geriatric Neurology. Upper Saddle River, NJ: Prentice-Hall; 2011. 


\title{
Neurology
}

\author{
The art of preserving personhood \\ Daniel C. Potts \\ Neurology 2012;78;836-837 \\ DOI 10.1212/WNL.0b013e318249f789
}

\section{This information is current as of March 12, 2012}

\section{Updated Information \& Services \\ Supplementary Material \\ Subspecialty Collections}

Permissions \& Licensing

Reprints including high resolution figures, can be found at: http://n.neurology.org/content/78/11/836.full

Supplementary material can be found at: http://n.neurology.org/content/suppl/2012/03/11/78.11.836.DC1

This article, along with others on similar topics, appears in the following collection(s):

\section{All Cognitive Disorders/Dementia}

http://n.neurology.org/cgi/collection/all_cognitive_disorders_dementia All Education

http://n.neurology.org/cgi/collection/all_education

Alzheimer's disease

http://n.neurology.org/cgi/collection/alzheimers_disease

Medical care

http://n.neurology.org/cgi/collection/medical_care

Quality of life

http://n.neurology.org/cgi/collection/quality_of_life

Information about reproducing this article in parts (figures,tables) or in its entirety can be found online at:

http://www.neurology.org/about/about_the_journal\#permissions

Information about ordering reprints can be found online:

http://n.neurology.org/subscribers/advertise

Neurology ${ }^{\circledR}$ is the official journal of the American Academy of Neurology. Published continuously since 1951, it is now a weekly with 48 issues per year. Copyright Copyright (? 2012 by AAN Enterprises, Inc.. All rights reserved. Print ISSN: 0028-3878. Online ISSN: 1526-632X.

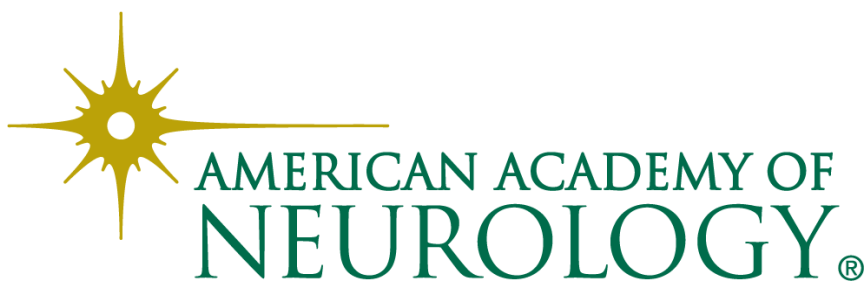

